\title{
Guillain-Barre Syndrome with Bilateral Peripheral Facial Nerve Paralysis Admitted to the Emergency Department
}

\author{
Acil Servise Bilateral Periferik Fasiyal Sinir Paralizisi ile Bașvuran Guillain-Barre Sendromu
}

\author{
Davut Kaplan, Engin Özakın, Arif Alper Çevik, Nurdan Acar, Göknur Yıldız
}

Eskișehir Osmangazi Üniversitesi Tıp Fakültesi, Acil Tıp Anabilim Dalı, Eskișehir, Türkiye

\section{ABSTRACT}

Facial nerve paralysis is a common disorder seen in the emergency room.It is mostly located unilaterally but bilateral facial paralysis rarely occurs. A 26 year old patient who presented with bilateral peripheral facial nerve paralysis due to the Guillain-Barré Syndrome is presented.

Keywords: Bilateral peripheral facial nerve paralysis, Guillain-Barre Sendrome

Received: 10.03.2011 Accepted: 04.05.2011

\section{ÖZET}

Fasiyal sinir paralizisi Acil Servis (AS)' te sık görülen durumlardandır. Genellikle tek taraflı yerleșim gösterir buna karșın bilateral fasiyal sinir paralizisi nadirdir. Bu yazıda 26 yașında bilateral periferik fasiyal sinir paralizisi nedeniyle gelen ve Guillain-Barre Sendromu (GBS) teșhisi konan olgu sunulmuștur.

Anahtar Kelimeler: Bilateral periferik sinir fasiyal paralizisi, Guillain-Barre Sendromu

Geliş Tarihi: 10.03.2011 Kabul Tarihi: 04.05.2011

\section{Giriş}

Fasiyal sinir paralizisi, fasiyal sinirin tek taraflı iskemik, enfeksiyöz ya da inflamatuvar nedenlerle geliștig̃i veya sinirin fallop kanaIına sıkışarak oluștug̃u kabul edilen klinik durumlardan biridir. Bilateral fasiyal sinir paralizisi nadirdir ve tüm paralizi hastalarının \%0.3-2 arasını olușturur (1). Yıllık insidansı 5 milyonda 1'dir (2). Etyolojisi çog̃unlukla belirlenebilir ve sıklıkla altta yatan ciddi bir hastalıg̃ın bulgusu olarak karșımıza çıkar. Bu durum ayrıntılı araștırmayı ve acil tedaviyi gerektirebilir. Bu makalede AS'e bilateral fasiyal sinir paralizisi klinig̃i ile gelen ve GBS tanısı alan hasta sunulmuștur.

\section{Olgu Sunumu}

Yirmi altı yașında, matbaa ustası, erkek hasta her iki tarafta yüz hareketlerinde güçsüzlük ve gözlerini kapatmakta zorluk nedeniyle AS'e başvurdu. Bir hafta önce bacaklarda ag̃rı ve güçsüzlük nedeni ile aile hekimi tarafından bog̃az enfeksiyonu düșünülerek amoksisilin tedavisi verilmiş. İki gün sonrasında kulaklarda ug̃ultu, ag̃ızda tatsızlık hissi, yüz kaslarında güçsüzlük bașlamıș. Sigara ve alkol kullanmayan hastanın fizik muayenede genel durumu iyi, şuuru açık, kooperasyon ve oryantasyonu tam, vital bulguları normal ölçüldü. Otolaringolojik muayenesinde iki taraflı fasiyal sinir paralizisi saptandı (her iki göz kapag̃ını kapatamama, yemek yeme ve konușmada zorlanma, her iki nazolabiyal oluklarda silinme ve alnını kırıștıramama) (Resim 1). Dig̃er kraniyal sinirler, nörolojik ve sistem muayenelerin de anormallik saptanmadı. Tam kan sayımı normal, biyokimya testlerinde patoloji saptanmadı. AS'te çekilen beyin bilgisayarlı tomografi (BT) ve beyin manyetik rezonans görüntülemeleri (MRG) normal olarak rapor edildi. Beyin omurilik sıvısı (BOS) incelemesinde basınç normal, görünüm berrak, protein: 95 mg/dL (normal deg̃er: 15-45 mg/dL), dig̃er parametreler normal sınırlardaydı. BOS mikroskopik incelemesinde hücre ve mikroorganizma görülmedi. Bu klinik, görüntüleme ve laboratuvar bulgularıyla hasta GBS düșünülerek Nöroloji servisine yatırıldı. Lyme lgM ve lgG negatif saptandı. Yirmi dört saatlik idrarda kalsiyum (Ca) negatif ve kanda anjiyotensin dönüștürücü enzim (ACE) aktivitesi normal bulundu. Hastaya 7 gün boyunca intravenöz immunglobulin 6x1 gr, göz koruyucu thilotears jel 4x1 verildi. Şikayetleri gerilemesi üzerine 10 gün sonra mestinon $2 \times 1$ tb, trental 2x1 tb, refresh ve viskotears göz damlası ile Fizik Tedavi ve rehabilitasyon poliklinig̃i önerilerek taburcu edildi. On beș gün sonra yapılan kontrolünde hastanın șikayetlerinin azaldıg̃ı görüldü. 


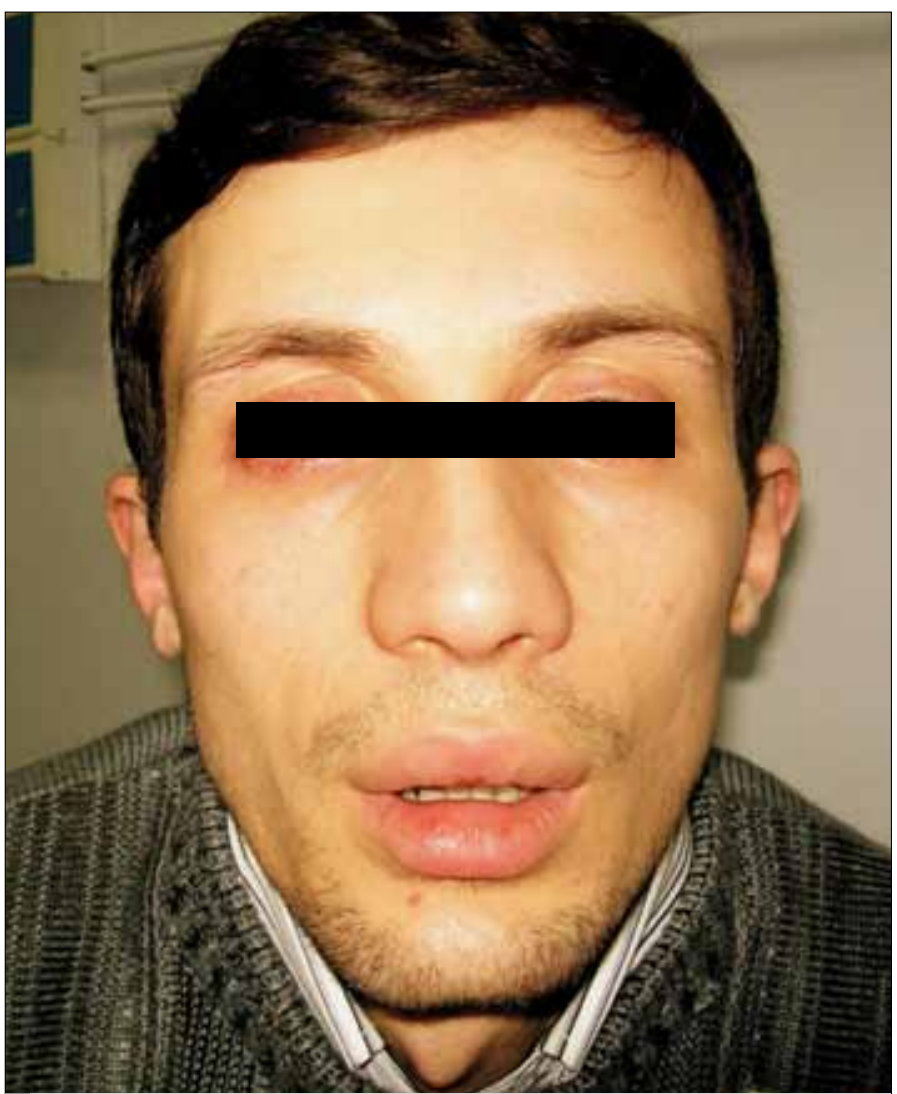

Resim 1. Bilateral fasiyal sinir paralizisi

\section{Tartışma}

Periferik fasiyal sinir paralizisi en sık karșılașılan nöropatilerdendir. En sık nedenleri herpes simplex virus aktivasyonuna baglı oldug̃u düșünülen idiyopatik periferik fasiyal sinir paralizisidir. Sıklıkla tek taraflı tutulum görülür. Bilateral fasiyal sinir paralizisi varlıg̃ında, etyolojik faktör sıkılıkla teșhis edilebilir ve genelde yașamı tehdit eden durumlardır. Bunlar arasında erișkin yaș grubunda Lyme hastalıg̃ı, GBS, lösemi, sarkoidoz, menenjit, sifiliz, Moebius sendromu, enfeksiyöz mononükleozis, kafa travmaları etyolojide rol oynayan sebepler iken çocuk yaș grubunda ise Lyme hastalıg̃ı, travma, idiyopatik, GBS, akut otitis media ve dog̃umsal fasiyal displeji en sık nedenler arasında yer almaktadır. Tam kan, biyokimya, BOS incelemesi, EBV, CMV, HSV, Lyme ve sifiliz (VDRL) testleri, ACE aktivitesi, mikrobiyolojik çalıșma, temporal kemik, beyin ve gög̃üs için $B T$, beyin $M R G$ gibi radyolojik inceleme gerekebilir.

Lyme hastalıg̃ı endemik bölgelerde fasiyal sinir paralizisinin sık nedenlerinden birisidir. Etken bir spiroket olan Borrelia Burgdorferidir. Fasiyal sinir paralizisi bu hastalarda \%11 oranında gözükürken \%23 bilateraldir (3). Ancak hastamızda endemik bölgeye seyahat öyküsü, eritema migrans bulgusu, karakteristik döküntü ve kene ısırıg̃ı hikayesi yoktu. Lyme anti lgM negatif saptandı.

Sarkoidoz etyolojisinin tam olarak bilinmedig̃i tipik olarak akcig̃er tutulumu ile karșımıza çıkan sistemik, kronik, granülomatöz bir hastalıktır (4). Nadiren fasiyal sinir paralizisinin tek nedeni olabilir. Nörolojik bulgular yaklașık \%5'i bunlarında \%50'sinde periferik fasiyal sinir paralizisi görülür (5). Hastamızda ölçülen idrar Ca, ACE testi negatif ve kranial MRG incelemesi normal olarak rapor edildi.

Sitemik lupus eritematozis ve Poliarteritis nodoza fasiyal sinir paralizisine neden olabilen dig̃er hastalıklardır (6). Hastanın bașvuru klinig̃i, laboratuvar bulguları ve normal MRG bizi santral sinir sistemini tutan lösemi, lenfoma ve malignitelerden dıșlamıș oldu. Literatürde belirtilen amiloidoz, sifiliz, poliomiyelit, tüberküloz ve porfiri gibi hastalıklar çok nadiren bu klinig̃e sebep olması ve hastanın klinik bulguları ile de uyumsuz olması nedeniyle öncelikli düșünülmemiștir (7).

Travmalar genellikle motorlu araç kazaları sonrasında görülür. Fasiyal sinir paralizisi temporal kemiklerde longitudinal kırıklar sonrasında olușabilir. Hastada travma öyküsü ve bulgusu yoktu.

Guillain-Barre Sendromu geçirilmiș bakteriyel ya da viral enfeksiyonun tetikledig̃i otoimmün, akut, sıklıkla ciddi ve fulminant seyreden poliradikülopatidir. En sık ve en erken bulgu parestezidir. Asıl bulgu, genellikle erken dönemde gelișen simetrik güçsüzlüktür. Distal kasların yanı sıra proksimal kaslar da etkilenebilir. Alt ekstremite sonrasında tutulum distal kaslar, interkostal kasların etkilenmesiyle solunum yetmezlig̃ine yol açarak mekanik ventilasyon ihtiyacı gerekebilir. Bașlangıçta kranial sinir tutulumu daha az gözükmekle birlikte çog̃unlug̃u bilateral olarak, fasiyal sinir paralizisi \%25-55, okulomotor parezi sıklıg̃ı \%5-13 arasında deg̃ișir (8). Dizartri ve disfajinin de eșlik ettig̃i dig̃er kraniyal sinir tutulumda görülebilir. Belirtiler, hastalıg̃ın ilerleme ritmi, akcig̃er tutulum derecesi, laboratuar bulguları ve iyileșme süresi büyük farklılıklar gösterir. Semptomlar genellikle viral enfeksiyonun geçirilmesinden 3-4 hafta sonra bașlar. Elektrofizyolojik testlere ilaveten hastamızda da oldug̃u gibi BOS analizinde GBS için hücre artıșı olmaksızın protein artışı ile karakteristiktir (9). Erken dönemde BOS deg̃erleri normal olabilir ancak normal olması GBS tanısını dıșlamamalıdır (9). BT ve MRG, GBS için tanı koydurucu olmamakla birlikte dig̃er sebepleri dıșlamak içinde yardımcıdır. Genelde intravenöz immunglobulin infüzyonu yanında destek tedaviler verilir. Prognoz genelde iyidir. Hastamızda GBS ön tanısı ile servise yatırılıp erken dönemde bașlanan tedavi ile verdig̃i olumlu yanıtla tanı dog̃rulanmıș ve hasta klinik olarak düzelmiștir.

\section{Sonuç}

Kendilig̃inden olușan bilateral periferik fasiyal sinir paralizisi çok nadirdir. Dog̃ru ve detaylı alınan öykü, tam fizik muayene, geniș ve kapsamlı laboratuar ve radyolojik incelemeler etyolojiyi aydınlatmak adına gereklidir ve bilateral periferik fasiyal sinir paralizisi ile gelen hastalarda GBS tanısını akılda tutmak gereklidir.

\section{Çıkar çatışması}

Yazarlar herhangi bir çıkar çatıșması bildirmemișlerdir.

\section{Kaynaklar}

1. Sharma OP. Neurosarcoidosis: a personal perspective based on the study of 37 patients. Chest 1997; 112: 220-8. [CrossRef]

2. Teller DC, Murphy TP. Bilateral Facial Paralysis: A case presentation and literature review. J Otolaryngol 1992; 21: 44-7.

3. Kilic R, Ozdek A, Felek S, Safak MA, Samim E. A case presentation of bilateral simultaneous Bell's palsy. Am J Otolaryngol 2003; 24: 271-3. [CrossRef] 
4. James DG. Differential diagnosis of facial nerve palsy. Sarcoidosis Vasc Diffuse Lung Dis 1997; 14: 115-20.

5. McIntosh WE, Brenner JF, Aschenbrenner JE. Bilateral facial paralysis as the sole presenting feature of sarcoidosis: report of a case. J Am Osteopath Assoc 1987; 87: 245-7.

6. Blaustein DA, Blaustein SA. Anti nuclear antibody negative systemic lupus erythematosus presenting as bilateral facial paralysis. Journal of Rheumatology 1998; 25: 798-800.
7. Price T. Bilateral simultaneous facial nerve palsy. J Laryngol Otol 2002; 116: 46-8. [CrossRef]

8. Holinger LD, Holinger PC, Holinger PH. Etiology of bilateral abductor vocal cord paralysis: A review of 389 cases. Ann Otol Rhinol Laryngol 1976; 85: 428-36.

9. Hauser SL, Asbury AK. Guillain-Barre syndrome and other immune-mediated neuropathies. In: Kasper DL, Harrison TR, eds. Harrison's principles of internal medicine 16th ed. New York: McGraw-Hill, Medical Pub. Division; 2005:2513-8. 